Winter 2009

\title{
Deliberative Democracy in Severely Fractured Societies
}

Adeno Addis

Tulane University Law School

Follow this and additional works at: https://www.repository.law.indiana.edu/ijgls

Part of the International Law Commons, and the Law and Politics Commons

\section{Recommended Citation}

Addis, Adeno (2009) "Deliberative Democracy in Severely Fractured Societies," Indiana Journal of Global Legal Studies: Vol. 16 : Iss. 1 , Article 4.

Available at: https://www.repository.law.indiana.edu/ijgls/vol16/iss1/4

This Symposium is brought to you for free and open access by the Law School Journals at Digital Repository @ Maurer Law. It has been accepted for inclusion in Indiana Journal of Global Legal Studies by an authorized editor of Digital Repository @ Maurer Law. For more information, please contact rvaughan@indiana.edu.

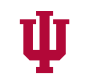

JEROME HALL LAW LIBRARY

INDIANA UNIVERSITY

Maurer School of Law
Blooming ton 


\title{
Deliberative Democracy in Severely Fractured Societies
}

\author{
AdENO AdDIS*
}

\begin{abstract}
The world is full of boundaries. Whatever their nature, boundaries provide the conditions for communal or individual identity and agency, and they make collective action possible. That very capacity to define and contain, however, allows boundaries to "close off possibilities of being that might otherwise flourish." Paradoxically, boundaries "both foster and inhibit freedom." This article explores how one particular boundary -ethnicity-has served both as an important source of identity and a cause of deep fracture in societies that this article calls "severely fractured." The purpose of the article is to explore what institutional structures and processes might be appropriate to respond to the challenges that severely fractured societies face. After examining the two well-known approaches-consociation and integration-that have dominated studies of, and prescriptions for, severely fractured societies, the article concludes that each unwisely underemphasizes one or another of the two necessary conditions for long-term stability in these societies: institutions that are both highly inclusive and have the capacity to foster interethnic dialogue. The article then outlines and defends a version of deliberative democracy that it argues responds to the needs of inclusion (pluralism) and the cultivation of interethnic dialogue. A well-structured deliberative process in the context of a highly inclusive institutional environment has the best prospect of transforming the hard parameters of ethnic identity into the soft parameters of diversity that this article argues will lead to a more sustainable form of pluralistic solidarity.
\end{abstract}

* William Ray Forrester Professor of Public and Constitutional Law, Tulane University Law School. For helpful comments on an earlier draft of this article, thanks go to Marjorie Kornhauser, Jonathan Nash, Keith Werhan, and participants at the Indiana Journal of Global Legal Studies Symposium on Operationalizing Global Governance which was held on March 19-21, 2008 at the Indiana University Maurer School of Law - Bloomington. This article is a revised version of the paper presented at that conference.

Indiana Journal of Global Legal Studies Vol. 16 \#1 (Winter 2009)

OIndiana University Maurer School of Law - Bloomington 


\section{INTRODUCTION}

The world is full of boundaries. There are boundaries that are marked by geography, by ethnicity, by race, by gender, and the like. Whatever their nature, boundaries provide the condition for communal or individual identity and agency, and they make collective action possible. That very capacity to define and contain, however, allows boundaries to "close off possibilities of being that might otherwise flourish." This is the paradox of boundaries that led one scholar to remark that "[b]oundaries both foster and inhibit freedom."

This article will focus on one particular boundary that has been both an important source of identity and a cause of deep division in many states: ethnicity. ${ }^{3}$ The article explores the following question: what institutional structures are appropriate for societies that are severely fractured along ethnic lines? ${ }^{4}$ The issue of how severely divided societies should cope with the challenges they face is of the highest practical importance and presents a significant conceptual challenge.

It is often said that the long-term stability and viability of severely fractured societies depend on their adoption of democratic institutions. Perhaps that is true. However, as Donald Horowitz observes, democracy defined as majoritarian rule is often a problem rather than a solution to the extent that it may (and often does) lead to the perpetual domination of one ethnic group by another. ${ }^{5}$ Long term sta-

1. William E. Connolly, The Ethics of Pluralization 163 (1995).

2. Id.

3. See Donald L. Horowitz, Ethnic Groups in Conflict, at xi (1985) ("The importance of ethnic conflict ... as a threat to be controlled, can no longer be denied.... Ethnicity is at the center of politics in country after country, a potent source of challenge to the cohesion of states and of international tension."). By "ethnicity" I mean to include racial, linguistic, and national differences as well. This is a view that the well-known Israeli Africanist Naomi Chazan expressed quite well when she observed that "[s]ometimes ethnic solidarity was expressed in cultural and linguistic terms. At other times ethnicity was presented in regional or geographic terms. And at still other points, ethnicity was manifested in local-communal-traditional political, territorial, or kin-terms." Naomi Chazan, Ethnicity and Politics in Ghana, 97 PoL. ScI. Q. 461, 467 (1982) (footnotes omitted).

4. For a definition of "severely fractured societies," see discussion infra Part II.

5. Donald L. Horowitz, Democracy in Divided Societies, J. Dem., Oct. 1993, at 18, 29 ("In ethnically divided societies, majority rule is not a solution, it is a problem, because it permits domination apparently in perpetuity.... If Britain were an ethnically divided society ... and the Conservatives, Labourites, and Liberal Democrats each represented a single ethnic group, the claim of permanent tyranny of a minority would be extremely plausible."). Writing about the recent violent turmoil in Kenya that followed the highly dispured election result, Gettleman observed: "The roots of the problem go deeper than the disputed election, in which the incumbent president, Mwai Kibaki, was declared the winner over the top opposition leader, Raila Odinga, despite widespread evidence of vote rigging. . . Part of the trouble is the winner-take-all system in Kenya, which hap- 
bility is also a function of both how inclusive the institutions are and whether those institutions provide the condition for sustained interethnic interaction that might lead to some level of interethnic cohesion or perhaps even solidarity, ${ }^{6}$ however thin it may be. In this article, I will outline and defend a version of deliberative democracy, which I argue best responds to the needs of both inclusion and cohesion that are essential for dealing with the problems afflicting these societies. I shall also briefly contrast this approach with two well-known approaches that have dominated studies of, and prescriptions for, severely fractured societies.?

\section{THE IsSuE}

A few years ago, a leading scholar of ethnic conflict made the following observation: "If the nineteenth was the century of Christian missionaries, the twenty-first may become the century of constitutional missionaries." ${ }^{\prime 8}$ This observation was made in 2000 following the collapse of the Soviet Union and its client regimes in Eastern Europe. Many American and West European constitutional scholars and policymakers traveled to these newly independent countries to offer advice on how best to structure their basic laws (constitutions). That period is well behind us, but the work of constiturional missionaries continues. There are many countries in the developing world struggling to design constitutions, and these scholars and policy makers continue to act formally as advisers and informally as something more. Most of these countries can be described as severely fractured societies where ethnicity has become a political cleavage such that political parties and interests are defined by and organized around it. Therefore, the task, whether it is for the missionaries or the natives, is how to devise accommodating institutions in a world of (severely) divided loyalties.

pens in much of Africa, where leaders often favor members of their own ethnic group and in the process alienate large swaths of the population." Jeffery Gettleman, Signs in Kenya of a Land Redraun by Ethnicity, N.Y. Times, Feb. 15, 2008, at A1; see also Kamuli Kasara, Tax Me if You Can: Ethnic Geography, Democracy, and the Taxation of Agriculture in Africa, 101 AM. POL. SCI. REv. 159, 159 (2007) ("Case studies from a number of countries highlight instances in which African leaders have distributed goods to members of their own ethnic group or to their home area.").

6. By "solidarity," I mean to refer to a condition that Richard Rorty described as a feeling of sympathy that is cultivated and enriched in a community of communication. RICHARD RORTY, CONTINGENCY, IRONY, AND SOLIDARITY 189-98 (1989).

7. See discussion infra Part III.C.1-2.

8. Donald L. Horowitz, Constitutional Design and the Problem of Adoption: Proposals Versus Processes, in The Architecture of Democracy: Constitutional Design, Conflict Management, And Democracy 15, 16 (Andrew Reynolds ed., 2002). 
The central issue of institutional design in severely fractured societies is how to devise structures and processes that can simultaneously capture the biography of the entire people in its complexities and provide conditions for the reconstituting and retelling of that biography. Seeing the issue this way emphasizes both the social fact of divided loyalties as well as their susceptibility to rearrangement and transformation through sustained institutional engagement among the various groups. The social fact of divided loyalties and competing identities suggests that the legitimacy of those institutions positively correlates with their degree of inclusiveness. This is what might be referred to as sociological legitimacy. Moreover, those institutions and processes must be normatively legitimate as well. They will be legitimate in the normative sense to the extent that they provide the conditions for the various groups to pursue fair terms of cooperation among themselves and, indeed, fair terms of imagining the state itself, both in historical and current terms. ${ }^{9}$ One critical task for ensuring normative legitimacy is to craft basic institutions in severely fractured societies that capture the reality of fracture in the context of promoting a democratic culture. ${ }^{10}$

A major task for political and legal theorists in the twenty-first century will be devising accommodating institutions in a world of divided loyalties. There are three major reasons for thinking thus. First, there are many severely fractured societies, especially in Africa and some parts of Asia, that need to develop such

9. This is similar to what Sujit Choudhry referred to as "constitutive constitutional politics" in Old Imperial Dilemmas and the New Nation-Building: Constitutive Constitutional Politics in Multinational Polities, 37 ConN. L. Rev. 933, 938 (2005).

10. I am aware that the notion of democracy is one of those "essentially contested concepts." For a description of the notion of "essentially contested," see W.B. Gallie, Essentially Contested Concepts, in The Importance of Language 121, 123 (Max Black ed., 1962) (The phrase "essentially contested concepts" is used to refer to concepts whose very nature is a source of disagreement.) and WILLIAM E. Connolly, The Terms of Political Discourse 10 ( $2 \mathrm{~d}$ ed. 1983) (following Gallie's understanding of "essentially contested concepts"). For the proposition that "democracy" is one of those contested concepts, see generally Arend Lijphart, Patterns of Democracy: Government Forms and PerforMANCE IN THIRTY-SIX CoUNTRIEs (1999) (arguing that vast international disagreement over democracy fits within the Galliean notion of an "essentially contested concept"). But the fact is that while the notion of democracy is understood in different ways among different societies and even among people within a particular society, most societies, including severely fractured societies, embrace some version of democracy, a central purpose of which is to provide the condition for equal participation of members of the relevant community. Now, not only is the concept of democracy contested, but there are times when missionaries of democracy use it as a subterfuge to achieve other, less principled goals in the same way that Christian missionaries in earlier times used the spread of the gospel as a subterfuge to promote other, more worldly goals. A bumper sticker on a car seen in western Sweden expressed this perfectly: "Be nice to America ... or we will bring democracy to your country." 
institutions if they are to survive as nation-states. ${ }^{11}$ Second, globalization and the large movement of people across national boundaries are making an increasing number of countries more diverse and thus creating competing loyalties and identities. One effect of globalization has been to heighten the tension between cosmopolitanism and localism, evident in the paradoxical way in which power and allegiances seem to be migrating from the nation-state. This migration is occurring in both upward and downward directions to super-national and sub-national institutions. Third, to the extent that devising international institutions is about accommodating peoples of differing and often competing identities, we may learn a great deal from attempts to devise accommodating institutions for severely fractured societies. Thus, the task of devising institutions that can accommodate diversity is not only the concern of deeply fractured nation-states but also of international and super-national organizations as well.

\section{Political and Constitutional Responses to Severely Fractured Societies: Types of System Transformation}

By invoking the term "severely fractured societies," I mean to refer to societies that are both "ethnically diverse and where ethnicity is a politically salient cleavage around which interests are organized for political purposes such as elections."'12

11. Pierre Trudeau, the former prime minister of Canada, in the course of defending Canadian federalism in the face of attacks from supporters of Quebec independence, argued that much of the world looks like Canada (ethnically fractured) and that it perhaps will be increasingly fractured and that the survival and flourishing of the Canadian experiment could serve as a guide for dealing with the "world-wide problems of ethnic pluralism." Pierre E. Trudeau, Federalism and the French Canadians 154, 178 (1968). Charles Taylor, the distinguished Canadian political theorist, made this same point decades later. The deep division in Canada, Taylor observes, is found "in many parts of the world today" and Canada "would do our own and some other peoples a favour by exploring the space of deep diversity." Charles Taylor, Shared and Divergent Values, in Reconciling the Solitudes 155, 183 (Guy Laforest ed., 1993).

12. Benjamin Reilly, Democracy in Divided Societies: Electoral Engineering for ConFLICT MANAGEMENT 4 (2001) (emphases omitted). The question of why voting patterns become ethnicized has elicited various answers. Some people, such as Samuel Huntington, view it as instinctual and inevitable. Samuel P. Huntington, The Clash of Civilizations and the Remaking of the WORLD ORdER (1996). Others attribute it to changes in the political environment (such as changes in jurisdictional or national boundaries). See, e.g. Horowitz, supra note 3. Still others emphasize functional reasons. Thus, for example, Fearon and Laitin suggest that shared language and shared social networks make political action easier to organize along ethnic lines. James D. Fearon \& David D. Laitin, Explaining Inter-Ethnic Cooperation, 4 AM. POL. SCI. REv. 715 (1996). Others have suggested that it is easy to provide patronage along ethnic lines. Kanchan Chandra, Why EThnic Parties Succeed: Patronage and Ethnic Headcounts in India 47 (2004). I shall not join the debate as to 
There are four factors that define severely fractured societies. First, they are fragmented along ethnic lines. Second, these divisions inform competing visions of the state as a whole and thus competing visions of national identity. ${ }^{13}$ The "severity" to which I refer here is therefore not just about the intensity of the conflict but also about the fundamental nature of the conflict, although it is often the case that the two are closely connected. Third, as a result of these deep and thick identities competing to define the nature of the state itself, majoritarian or aggregative democracy is often a problem rather than a solution. As Horowitz notes, "[i]n ethnically divided societies, majority rule is not a solution; it is a problem, because it permits domination, apparently in perpetuity." ${ }^{\prime 14}$ Additionally, as Adam Przeworski has noted, the stability of electoral democracy rests on the losers accepting defeat in the expectation that they might be able to win in subsequent elections; this is not a realistic expectation when majoritarian democracy is utilized in severely fractured societies. ${ }^{15}$ Fourth, though fair distribution of resources might certainly ease the fractures in these deeply divided societies, it will not be the entire answer, for the issues at stake here are not merely, or even primarily, issues of distribution of resources, but rather issues of identity. Here is where many political theorists,

why ethnicity becomes salient in severely fractured societies. For my purpose here, I shall assume that there is some truth to both the functionalist and non-functionalist arguments.

13. See John Dryzek, Deliberative Global Politics: Discourse and Democracy in a Divided WORLD 46 (2006) ("A divided society is defined by mutually contradictory assertions of identity."); Lahra Smith, Voting for an Ethnic Identity: Procedural and Institutional Responses to Ethnic Conflict in Ethiopia, 45 J. MOD. AFr. STUD. 565, 567 (2007) ("Conflicts over the most appropriate political institutions in multiethnic states frequently indicate competing visions of citizenship, not just competing political interests."). See generally Rogers Brubaker, Nationalism Reframed (1995); Jack L. SnYder, From Voting to Violence: Democratization and National Conflict (2000).

14. Horowitz, supra note 5, at 29; see also Arend Lijphart, Power-Sharing in South Africa 19 (1985) (“[M]ajority rule in plural societies spells majority dictatorship and civil strife.”). John Dewey's observation about majority rule is worth noting here. Dewey observed: "Majority rule, just as majority rule, is as foolish as its critics charge it with being. But it never is merely majority rule... 'The means by which a majority comes to be a majority is the more important thing: antecedent debates, modification of views to meet the opinions of minorities... The essential need, in other words, is the improvement of the methods and conditions of debate, discussion and persuasion." JOHN DEWEY, The Public and Its Problems 207-08 (Swallow Press 1991) (1927) (quoting Samuel J. Tilden).

15. Adam Przeworski, Democracy and the Market: Political and Economic Reforms in EASTERN EUROPE AND LATIN AMERICA 23-24 (1991). Of course, losers could also accept the result if they fear the consequence of the breakdown of order more than they hate perpetual losing. But the fear of disorder will not serve as a disincentive for long if that order is purchased at the high price of perpetual subordination. 
even distinguished ones, err. They assume that a just distribution of resources will fully respond to the problems afflicting severely fractured societies. ${ }^{16}$

What are the available responses to the challenges of ethnic divisions and conflicts ${ }^{17}$ Of course, separation (secession, as it is formally known) is an option, ${ }^{18}$ but in most cases such separation is neither feasible nor an adequate solution to the problem. It is not feasible because there are so many severely fractured societies that any attempt to solve the problem of deep division by providing for the process of political divorce is likely to lead to chaos, especially in Africa and perhaps parts of Asia and the Middle East. ${ }^{19}$ In any case, in many circumstances the various ethnic groups do not occupy clearly defined geographic areas, which make it impossible for any sensible process of separation to occur. It is also the case that in a large number of circumstances, separation is not the desire of the groups, although each may wish to define the state in its own ethnic image. Even if separation were feasible, it would be unlikely to provide a long-term solution. There are two reasons for this. First, a

16. For an example of such a view, see generally Brian M. Barry, Culture \& Equality: AN Egalitarian Critique of Multiculturalism (2001).

17. Of course, one could employ what I have elsewhere in another context called the Ostrich approach, which would deny the existence of ethnic division in the country until it explodes. Adeno Addis, Cultural Integrity and Political Unity: The Politics of Language in Multilingual States, 33 ARIz. ST. L.J. 719, 730-33 (2001). But that is not much of a response.

18. As Thomas Chapman and Philip Roeder note: "In the midst of civil wars in such diverse countries as Serbia, Somalia, Iraq and Indonesia analysts have asked whether peace would be more secure and democracy would be more likely to flourish if we portioned those countries rather than attempted to keep them whole." Thomas Chapman \& Philip G. Roeder, Partition as a Solution to Wars of Nationalism: The Importance of Institutions, 101 AM. PoL. SCI. REv. 677, 677 (2007). Indeed, no lesser authority than John Stuart Mill thought that "[f]ree institutions are next to impossible in a country made up of different nationalities." JoHn StUaRT MiLl, ON LiberTy and CONSIDERations ON RePRESENTATIVe Government 292 (R.B. McCallum ed., Basil Blackwell 1947) (1859). For Mill, the condition for living together is a sense of "fellow-feeling" which for him will not be there among people speaking different languages. Id. The logical terminus of this observation is that under those circumstances political divorce is the only option. Eritrea separated from Ethiopia; and Slovakia and the Czech Republic went their separate ways at the end of the collapse of communism in the Soviet Union and Eastern Europe. Recently, we saw Kosovo take that route, separating from Serbia, although that situation seems to remain highly disputed and volatile.

19. See James Tully, Strange Multiplicity: Constitutionalism in an Age of Diversity 8 (1995) ("As writers as different as Ernest Gellner and David Maybury-Lewis have argued, the consequence [of recognizing every "nation" as a country] is impractical."). Eighty percent of African borders run along latitudinal and longitudinal lines, and the borders drawn by colonial powers do not coincide with cohesive ethnic or national groups. In other words, colonizers created fragmented societies by drawing artificial boundaries. Pierre Englebert et al., Dismemberment and Suffocation: A Contribution to the Debate on African Boundaries, 35 Comp. PoL. STud. 1093, 1094-95 (2002); see also William Easterly \& Ross Levine, Africa's Growth Tragedy: Political and Ethnic Divisions, 112 Q.J. OF Econ. 1203, 1205-06 (1997) (arguing that ethnic fragmentation reduces consensus for public goods). 
new unit is likely to have some ethnic minorities within itself, and those minorities may have the same sort of concerns that the majority in the new unit had when it was (a minority) part of another country. ${ }^{20}$ If this were the case, it would again raise the question of how different groups with sharp and contrasting identities can live together. ${ }^{21}$ Second, and even more worrying, the new unit may engage in some sort of ethnic cleansing to purge itself of future ethnic problems, especially if a minority ethnic group borders a state run by co-ethnics. ${ }^{22}$

Consociation has been championed as perhaps the best way to manage ethnic cleavages in severely fractured societies. ${ }^{23}$ Consociational democracy advocates for mechanisms that would allow political elites within the various ethnic groups to

20. For example, in Ethiopia "[n]one of nine regional states is mono-ethnic." Jon Abbink, Ethnicity and Constitutionalism in Contemporary Ethiopia, 41 J. Afr. L. 159, 163 (1997) (citing census reports on the various regional states). This is especially the case in two of the states where there are active secessionist groups (the Oromia and Somali states).

21. Kosovo declared its independence from Serbia over the vehement opposition of both the Serbian state and Serb minorities in Kosovo itself. Kosovo's Serb population "greeted the secession as though it were amputation. Many vowed not to accept the loss of a region they consider the heart of their homeland." William J. Kole, In Kosovo It's 'Independence Eve', ABC NEws, Feb. 17, 2008, http://abcnews.go.com/print?id=4301312. It is not just the fact that secession might paradoxically reproduce the problem that led to the claim of secession, but that it also raises the issue of injustice. See, e.g., Chaim Gans, National Self-Determination: $A$ Sub - and Inter-Statist Conception, 13 CAN. J.L. \& JURISPRUDENCE 185 (2000) (viewing self-determination in terms of secession hides the fact that often it is a majority that decides to have its own state and a minority that wishes not to secede (even if it participates in the voting) will have been treated unjustly). But, of course, the injustice could be avoided if self-determination is viewed as establishing a state consisting of one nation and one nation alone. One author viewed this as the ideal condition. See Daniel Philpott, In Defense of Self-Determination, 105 ETHics 352, 359 (1995) ("The ideal group's ideal borders encompass all those who share its identity, and only those who share its identity."). But unless one engages in ethnic cleansing, no such ideal condition exists.

22. The removal of ethnic groups from one state to another could come about in three ways. One state could make the life of an ethnic minority so intolerable that members of that minority flee to the land of their co-ethnics. This, for example, could happen in Kosovo. There could also be extensive exchange of population between two neighboring states, which of course is a form of ethnic cleansing, dislocating people from their homes and transferring them to another country. This is exactly what happened between India and Pakistan at the time of the partition and between Greece and Turkey after the Treaty of Lausanne. "More than a million Greeks were sent from Turkey to Greece, and a smaller number of Turks from Greece to Turkey, thereby drastically reducing diasporic presence on both sides of the border." YOSSI SHAIN, KINSHIP AND DIASPORAS IN INTERNATIONAL AFFaIRS 14 (2007). There could also be an exchange of territories that are inhabited by coethnics. This last option is in my view the least offensive.

23. See Arend Lijphart, Constitutional Design for Divided Societies, J. DEM., Apr. 2004, at 96, 99 (Consociation "offers the best fit for most divided societies regardless of their individual circumstances and characteristics."). 
share power (a system referred to as a grand coalition). ${ }^{24}$ Power sharing could take various forms, but an important ingredient is proportional representation of all significant groups in the machineries of government, such as legislative bodies, the executive department, and civil service jobs. Another feature of consociation is the power of minorities to veto major decisions, which means that key decisions would need a high degree of consensus if they were to be adopted. ${ }^{25}$ Consociational democracy is clearly an alternative to majoritarian or aggregative democracy because it prevents perpetual domination of ethnic minorities by ethnic majorities. Consociationalism is premised on the notion that ethnic groups are likely to organize along ethnic lines, and thus aggregative majoritarianism will be a mechanism of exclusion rather than inclusion. Consociational democracy has been criticized as encouraging rather than discouraging strident ethnic politics to the extent that it endorses and reinforces the combination of ethnic-based parties and proportional representation. ${ }^{26}$ The argument here is that consociationalism does not provide incentives for ethnic parties to make appeals across ethnic lines; therefore, politics would continue to be seen as a zero-sum game for each ethnic party. Critics contend that this will not only distort political outcomes but also that it does not encourage long-term stability. I generally agree with these sentiments.

In contrast to a consociational democracy, an incentive-based or integrationist democracy, often associated with the work of Donald Horowitz, recommends designing institutions that will provide "political incentives to encourage interethnic moderation." ${ }^{\text {nz }}$ The task here is to induce moderate behavior on the side of elected officials by requiring them to depend on the votes of groups other than their own in order to be elected to office. As Horowitz put it, the integrationist model does not seek to reverse majoritarian practices but rather "aims at majori-

24. As the most prominent advocate of consociationalism, Arend Lijphart said: "The primary characteristic of the consociational democracy is that the political leaders of all significant segments of the plural society cooperate in a grand coalition to govern the country." AREND LIJPHART, DEMOCRACY IN PluRal Societies 25 (1977).

25. See Arend Lijphart, Varieties of Nonmajoritarian Democracy, in DEMOCRACY AND INSTITUTIONS: The Life Work of Arend LijPHART 225, 228 (Markus M. L. Crepaz et al. eds., 2000) (The consociational model involves "grand coalition, segmental autonomy, proportionality, and minority veto.").

26. Donald L. Horowitz, Constitutional Design: An Oxymoron?, in Designing Democratic InstiTUtIONS 253, 258-59 (Ian Shapiro \& Stephen Macedo eds., 2000). One of the early and trenchant critiques of consociational democracy is in Brian Barry, Political Accommodation and Consociational Democracy, 5 Brit. J. Pol. Sci. 477, 477-505 (1975) (reviewing Arend LiJPHart, The Politics of ACCOMMODATION (1975)).

27. Donald L. Horowitz, The Cracked Foundations of the Right to Secede, J. DEM., Apr. 2003, at 5 , 15; see also Horowitz, supra note 26, at 262. 
tarian decisions by moderate, interethnic center." ${ }^{28}$ The integrationist approach's emphasis on incentives for moderation attempts to deal with an aspect of the problem that consociation fails to address: the prospect of permanent warring factions. ${ }^{29}$ As I shall argue in the next section, while consociation emphasizes inclusion at the expense of the cultivation of a national community, identity, or common political purpose, the integrationist approach pursues moderation-a common political purpose, perhaps at the expense of full inclusion. ${ }^{30}$ Indeed, the whole purpose of electoral engineering, as far as the integrationists are concerned, is to marginalize those considered extremists and to elect only those who will occupy the imperial center (the moderates). As I shall argue later, this approach is likely to lead to a truncated deliberative process after the election to the extent that the substance of deliberation has been electorally narrowed..$^{31}$

Another approach to the problem is a version of deliberative democracy I shall outline and defend in the next section. This version is sensitive to both inclu-

28. Horowitz, supra note 26, at 259; see also Donald L. Horowitz, A Democratic South AfriCA? 165 (1991).

29. The agonists will of course think that this is perfectly acceptable to the extent that enemies are transformed into adversaries. Agonists argue that the main task of democracy is to convert antagonism into agonism and enemies into adversaries, for they believe that deliberation is incapable of processing deep differences. See generally William E. Connolly, IDENTITY/DiffERENCE: Democratic Negotiations of Political Paradox 4 (1991); Bonnie Honig, Political Theory and the Displacement of Politics (1993); Chantal Mouffe, The Democratic Paradox (2000); Chantal Mouffe, Deliberative Democracy or Agonistic Pluralism?, 66 Soc. REs. 745 (1999).

30. For example, a party that advocates secession may find it difficult to win under the integrationist model. Perhaps the process is meant to exclude such groups from the conversation. Many fractured societies continue to suffer instability and even destructive conflicts as a result of defining those who are not yet convinced of the value of continuing the marriage as outside the circle of acceptable dialogue partners. Turkey provides the clearest example. The Turkish Constitution requires the Constitutional Court to dissolve permanently any political party whose "statutes and programmes, as well as [its] activities [are] in conflict with the independence of the state, its indivisible integrity with its territory and nation." Constitution of the Republic of Turkey arts. 68, 128. This constitutional provision and laws passed pursuant to it have been used to exclude Kurdish nationalists from the national conversation. In the same way that states used to exclude anti-democratic groups from the electoral process on the principle of "the right to democratic self-defense," many fractured societies have made it difficult for secessionist parties to take part in the political process on the ground of "nationalist selfdefense." But of course the issue in most of these societies is precisely what the nations should look like. For the notion that democracies have the right to defend the democratic process and the integrity of the territorial state, see discussion in Samuel Issacha roff, Fragile Democracies, 120 Harv. L. REv. 1405, 1421-51 (2007).

31. In the Horowitzian approach there is the possibility of robust deliberation, but it takes place at the time of the campaign rather than after it. Michael Rabinder James, Deliberative DemocRaCy \& THE Plural Polity 190 (2004) ("Horowitz's approach, on the other hand, locates plural deliberation at the campaign level."). 
sion (pluralism) and the cultivation of interethnic dialogue, which has the prospect of transforming the hard parameter of ethnic identity into a soft parameter of diversity in the context of an equally soft but sustainable cohesion. ${ }^{32}$ I shall refer to that version of deliberative democracy as pluralistic solidarity to indicate that the approach will simultaneously affirm and accommodate multiple identities in a particular territorial community while at the same time cultivating a notion of "we the people" at the national level.

The notion that deliberation or discourse is essential for transforming hard parameters into soft ones is premised on the proposition that identities are partly bound up with discourse, and what has been imagined through stories and discourses can partly be reimagined through discourse as well. In this sense, Benedict Anderson's observation about nations - that they are partly imagined—could easily apply to ethnic groups. ${ }^{33}$ But to say that ethnic groups are imagined is not to say that they are therefore unreal or false. ${ }^{34}$

32. For the distinction between soft and hard parameters, see Ronald Dworkin, Foundations of Liberal Equality, in 11 The Tanner Lectures on Human Values 1, 70 (Grethe B. Peterson ed., 1990).

We must distinguish between what I shall call hard and soft parameters. Parameters, as I said, enter into the description of any challenge or assignment: they describe the conditions of successful performance. Hard parameters state essential conditions: if they are violated the performance is a total failure, no matter how successful in other respects.... Soft parameters are those aspects of assignment that, when violated, reduce the value of the performance but do not annihilate it: they act as standards of good performance that permit defects to be compensated by high success against other standards.

Id.

33. Benedict R. Anderson, Imagined Communities: Reflections on the Origin and Spread OF NATIONALISM 6 (rev. ed. 1991) (The nation "is an imagined political community-and imagined as both inherently limited and sovereign. It is imagined because the members of even the smallest nation will never know most of their fellow-members, meet them, or even hear of them, yet in the minds of each lives the image of their communion.").

34. Id. ("In fact, all communities larger than primordial villages of face-to-face contact (and perhaps even these) are imagined. Communities are to be distinguished, not by their falsity/genuineness, but by the style in which they are imagined."). 


\section{Deliberative Democracy in Severely Fractured Societies: The Case for Pluralistic Solidarity}

\section{A. The Nature of Deliberative Democracy}

Deliberative democracy emerged as an alternative to aggregative majoritarianism. Although context is important in the development and elaboration of deliberative democracy, the central principles of deliberative democracy could be summarized as follows: at the heart of a genuine process of deliberation is the idea that collective decision making is to proceed in a manner in which participants advance proposals and propositions. Participants must then defend those proposals with reasons that are accessible to and acknowledged as reasons by fellow participants whose only motivation is the cooperative search for the truth or the most defensible result or arrangement. ${ }^{35}$ An implicit requirement of a genuine deliberative process is that all participants are treated as free and equal with reasonable commitments of their own. The reason-giving requirement of dialogue, or discourse, as Jürgen Habermas refers to it, ${ }^{36}$ is a central requirement of deliberation. ${ }^{37}$ For a deliberative process to treat participants as free and equal, it must provide them with roughly equal institutional and material resources to engage in the dialogue. Such provisions would also likely enhance the pool of reasoned arguments. Furthermore, the very nature of the deliberative process of justification assumes that participants in collective de-

35. See Amy Gutmann \& Dennis Thompson, Why Deliberative Democracy? 7 (2004) (defining deliberative democracy as "a form of government in which free and equal citizens (and their representatives) justify decisions in a process in which they give one another reasons that are mutually acceptable and generally accessible, with the aim of reaching conclusions that are binding in the present on all citizens but open to challenge in the future."). Gutmann and Thompson observe that deliberation's "first and most important characteristic, then, is its reason-giving requirement... [These] are reasons that should be accepted by free and equal persons seeking fair terms of cooperation." Id. at 3.

36. See Júrgen Habermas, Between Facts and Norms: Contributions to a Discourse TheORY OF LAW AND DEMOCRACY 278-79 (William Rehg trans., Suhrkamp Verlag 1996) (1992) ("[Discourse theory] insists on the fact that democratic will-formation does not draw its legitimating force from the prior convergence of settled ethical convictions. Rather, the source of legitimacy includes, on the one hand, the communicative presuppositions that allow the better arguments to come into play in various forms of deliberation and, on the other, procedures that secure fair bargaining conditions."); see also GUTMANN \& THOMPSON, supra note 35, at 3.

37. See Joshua Cohen, Procedural and Substance in Deliberative Democracy, in Democracy AND Difference: Contesting the Boundaries of the Political 95, 99 (Seyla Benhabib ed., 1996) ("A deliberative conception [of democracy] puts public reasoning at the center of political justification."). Joseph M. Bessette calls deliberation the "mild voice of reason." Joseph M. BessetTE, THE MiLD Voice of Reason: Deliberative Democracy and american National Government (1994). 
cision making enter the dialogue with the view that "the reasons given, and the reasons responded to, have the capacity to change minds." ${ }^{\text {. }}$

Put simply, there are three conditions to a well-functioning deliberative system. First, all those who are expected to submit to laws and institutions of a polity have the right to participate fully and equally in the development of those institutions and laws. This can be referred to as the principle of deliberative equality. Second, these equal participants are to engage in a dialogue, advancing and defending proposals and propositions with reasons that are acknowledged as such by and accessible to others who are themselves free and equal participants. "[D]ecisions are not simply based on the counting of votes but also on the sharing of reasons." ${ }^{39}$ This reason-giving condition can be called the common pool of reason. Third, deliberative democracy assumes that each party comes to the dialogue with the motivation of reaching consensus or fair terms of cooperation. This can be referred to as the principle of reciprocity. Of course, it is in the nature of the deliberative process that decisions will lead to further dialogue and revision, as participants take into account the preferences and views of others, and in the process transform their own views and preferences. Conceived this way, deliberative democracy provides a better way of achieving long-term stability in severely fractured societies, for it ensures, or at a minimum has the potential for, both inclusion and connection. In this respect, deliberative democracy is more promising than consociation which cultivates inclusion, but often without providing the institutional means for connection. It is also more promising then integration, which highlights the need for connection by emphasizing moderation at the electoral level, often without paying due attention to the exclusionary aspect of that strategy.

\section{B. Deliberative Democracy in Severely Fractured Societies}

In severely fractured societies, the principle of deliberative equality counsels that no group with a sizable constituency should be excluded from the process of institutional dialogue on account of that group being militant--beyond the acceptable moderate spectrum - and hence a threat to the stability of the fractured polity. This is so for three reasons. First, excluding groups from the dialogic process is a violation of the principle of deliberative equality to the extent that a seg-

38. GutManN \& ThOMPSOn, supra note 35, at 20; see also DrYZEK, supra note 13 , at 27 ("For deliberation occurs whenever participants are amenable to changing their minds as a result of reflection induced by non-coercive communication."). Kwame Anthony Appiah captures the fact that disagreement presupposes the possibility of agreement when he notes: "Disagreement presupposes the cognitive option of agreement." Kwame Anthony Appiah, The Ethics of Identity 255 (2005).

39. Steven Wheatley, Deliberative Democracy and Minorities, 14 EUR. J. INT'L L. 507, 509-10 (2003). 
ment of the population for whom that group speaks is left unrepresented. ${ }^{40}$ Second, the exclusion diminishes the aggregate pool of reason for the deliberative process and may consequently undermine the capacity of the deliberative process to lead to fair terms of cooperation. Third, as an empirical matter, it is likely that an excluded group will, along with its supporters, believe that it has been shut out from playing any role in creating the identity of "we the people" and thus will be more of a threat from the outside than it would be from within. The incentivebased (or integrationist) approach that attempts to ensure stability by electorally engineering an imperial middle will be unlikely to ensure stability and cohesion. A lasting stability will come about only as a result of a moderation that is born of dialogue rather than one that is electorally engineered. What is needed is not an ex ante preclusion of a group or a group's interest but a deliberative process that will induce reflection among groups on those interests.

As I noted earlier, consociation clearly satisfies the principle of deliberative equality to the extent that its goal is the inclusion of all groups with a sizable constituency in a national grand coalition. But it is also reasonable to assume that elite-dominated grand coalitions, where each group's (at least each extremist group's) long-term prospect as part of the coalition is dependent on the continuation of sharp differences among the various groups, may not provide the condition for interethnic, reasoned dialogue with fair terms of cooperation as the goal. This becomes even more evident when one realizes that proportional representation is accompanied by minority veto powers. If groups view their continued existence as depending on practicing strident ethnic politics and if minority veto power is exercised to protect the ethnic status quo, then genuine deliberation with fair terms of cooperation as its goal would not be possible. ${ }^{41}$ In the next section, I will explore institutional structures that would minimize such tendencies and maximize the chances of interethnic dialogue.

40. A 1995 resolution of the United Nations Human Rights Commission (recently renamed the United Nations Human Rights Council) makes the point. Comm'n on Human Rights Res. 1995/60, II 11, U.N. Doc. E/CN.4/RES/1995/60 (Mar. 7, 1995). Deliberation requires that "all tendencies, interests and feelings" obtain representation within government. Id.

41. This is the point Brian Barry made with considerable force over three decades ago. See generally Barry, supra note 26. 


\section{Institutionalizing Deliberative Democracy in Severely Fractured Societies}

If deliberative democracy is to be of any use to severely fractured societies, it needs to take institutional designs seriously, ${ }^{42}$ however difficult that may be. What types of institutional structures would be conducive to a deliberative form of democracy that will ensure long-term stability and perhaps even solidarity? Each fractured society has its own specific history and specific points of fracture, and institutions will have to respond to those needs and histories. But there are a few general principles that, though not exhaustive, might be suggested as conducive to deliberative democracy. The general principles come in the form of "do's" and "don'ts." That is, there are certain matters that need to be institutionalized and others that ought not be part of the formal institutional processes if genuine deliberative democracy is to be fostered.

\section{The Vice of Constitutionalizing the Right to Secede}

Some ethnically divided societies, such as Ethiopia, provide for the right to secede in their constitutions. ${ }^{43}$ The constitutionalization of such a right can be defended on two grounds. First, it may be said to send an important signal to the various ethnic groups or nations, as they are called in some countries, that this is a voluntary union and divorce is available if it appears that the marriage is not working (or not working well) for any of the parties. Second, the availability of secession as a constitutional right may lead the various ethnic groups to attempt the union, which they might not have done were that right not available. Neither ground seems persuasive. One does not need to insert a right to secession in the constitution to realize that any continued union in fractured societies will be possible only to the extent that it is a voluntary association. No one can keep a group as part of the union by force for any significant length of time; conversely, no group that is determined to keep a country united will shy away from using force to achieve that objective, even if there is a right to secede in the constitution, as was the case with the former Soviet

42. See Peter McLaverty \& Darren Halpin, Deliberative Drift: The Emergence of Deliberation in the Policy Process, 29 INT'L POL. SCr. REv. 197, 198 (2008) (“[F]or scholars interested in political deliberation, the focus of attention should be on the design of institutions which are likely to promote deliberation between participants.").

43. See Constitution of the Federal Democratic Republic of Ethiopia art. 39(1)(a). "Every Nation, Nationality or People in Ethiopia has an unconditional right to self-determination, including the right to secession." Id. This right is thought to belong to a group of fundamental rights that cannot be suspended even under emergencies threatening the life of the nation. See id. art. 93(1)(a). 
Union $^{44}$ and the current regime in Ethiopia. ${ }^{45}$ As for the notion that such a right will incline groups to try out the marriage, it is not entirely clear why that would be so and what the value of a trial is if the very reason that led them to try it ends up undermining the long-term stability of the marriage.

Even if one were to agree that there is some merit to the arguments in support of constitutionalizing the right to secession, the existence of such a right will have a significant negative impact on the deliberative process and on the long-term viability of the union. This is so for a number of reasons. First, to provide for a right of secession at that initial moment, when passion, and perhaps the desire to exit, is still high, is to seriously undercut even the possibility of a good beginning of a genuine, cooperative endeavor with fair terms of cooperation as its goal. Second, even in the long term, such a right is likely to be used strategically, especially by those in resource-rich areas, to extract more than their fair share both in terms of resource allocations and power sharing. ${ }^{46}$ That will clearly be inconsistent with a genuine deliberative process and will not ensure long-term stability. ${ }^{47}$ Genuine deliberation assumes not just equality of participants but also the principle of reciprocity - that parties are engaged in a common political enterprise and that they owe each other "justifications for the mutually binding laws and public policies they collectively enact. ${ }^{, 48}$ Strategic behavior is not conducive to that. ${ }^{49}$

Third, the right to secession is likely to divert the process of deliberation from

44. "Article 17 of Stalin's 1936 constitution and Article 72 of the constitution that replaced that one in 1977 , both proclaim that 'Each Union Republic shall retain the right freely to secede from the USSR.' Of course . . . it is presumed that the Kremlin leaders did not seriously entertain the possibility of this right actually being exercised." Wayne Norman, Negotiating Natronalism: Nationbuilding, Federalism, and Secession in the Multinational State 176 (2006).

45. The rather brutal way that the government has dealt with the secessionist movement of the Oromia and Somalia states over the years is an indication that the government does not have any intention of allowing discussion about secession.

46. It is true that anything could be used for strategic purposes, such as natural resources, even when there is no right to secede, but it seems to me that the availability of secession will increase strategic behavior significantly.

47. See Cass Sunstein, Designing Democracy: What Constitutions Do 102 (2001).

48. Gutmann \& Thompson, supra note 35 , at 98.

49. To understand the difference between strategic and deliberative politics, it might be useful to turn to Jürgen Habermas's distinction between instrumental or strategic rationality on the one hand and communicative rationality on the other hand. See Jurgen Habermas, The Theory of CommuNicative Action: Reason and the Rationalization of Society 82-101, 256-88 (Thomas McCarthy trans., 1984). According to Habermas, instrumental or strategic rationality occurs when parties approach communication or interaction with the aim of defeating all opposing views and are unwilling to listen to and reflect on the views of others. See id. On the other hand, communicative rationality-the equivalent of deliberative politics-is a process of entering into communication with an 
one involving a particular subunit and other subunits within the relevant nationstate to one involving that subunit and a neighboring country, if that country is run by co-ethnics. Put simply, the right will encourage irredentism ${ }^{50}$ more than it would deliberation with fair terms of cooperation as its goal. Many severely divided societies, including Ethiopia, have irredentist groups, and constitutionalizing the right to secession will discourage rather than encourage a genuine deliberative process within the societies themselves. ${ }^{51}$ To sum up, the constitutionalization of the right to secession is more likely than not to lead to a "seemingly never-ending, secessionist politics [that] can be as unfortunate for the larger state as secession itself."52

To argue that a right to secession will have a negative impact on the deliberative process is not to deny that secession may in fact be the only option under certain circumstances, where the marriage is simply unworkable and a particular group continues to be dominated in a morally arbitrary way. ${ }^{53}$ Rather, it is to observe that the explicit provision of a right to secession in a constitution would undermine the process of open and sincere deliberation about fair terms of cooperation, and that if the marriage has failed miserably, the lack of a right to

open mind and a willingness to listen to the argument of others and be swayed by the force of the argument. See id.

50. "Irredentism" is defined as a process "when one ethnic group attempts to secede to join co-ethnic communities in other states." James Habyarimana et al., Is Ethnic Conflict Inevitable?: Parting Ways Over Nationalism and Separatism, FoREIGN AFF., July-Aug. 2008, at 138, 139. Horowitz defines it with the emphasis not on the separatists but on the potential incorporators, as "the attempt to detach land and people from one state in order to incorporate them in another ... [or] the attempt to detach land and people divided among more than one state in order to incorporate them in a single new state ...." Donald L. Horowitz, Irredentas and Secessions: Adjacent Phenomena, Neglected Connections, in IRREDENTISM AND INTERnational POLitics 9, 10 (Naomi Chazan ed., 1991). An example of the first kind of irredentism is the Somalis in Ethiopia who are often desire to join Somalia, a goal encouraged by successive Somali governments. See id. An example of the second type is the aspiration of the Kurds in Turkey, Syria, Iran and perhaps even Iraq to constitute themselves as a country called Kurdistan. See id. See generally HorowrTz, supra note 3, at 281-88; Horowitz, supra note 27, at 5, 10-14.

51. In the case of Ethiopia, federal units are drawn generally along ethnic lines. One of the units (the Ogaden) is in fact named the Somali State. Somalia borders this Somali State and successive governments have laid claims to the area. To insert a right to secession and to name the unit with exactly the same name as the neighboring state is to go a long way to undercut the possibility of genuine deliberation within the country.

52. NORMAN, supra note 44, at 197. I must note here that Norman makes the point to support (rather than to oppose, as I do here) the constitutionalization of the right to secede.

53. See generally Allen Buchanan, Toward a Theory of Secession, 101 ETHICs 322 (1991), for a thoughtful exposition of the conditions which might justify secession. Also, see generally SECESSION and Self-Determination (Stephen Macedo \& Allen Buchanan eds., 2003), especially the essays by Allen Buchanan and Wayne Norman, and Allen E. Buchanan, Justice, LegitimaCY, and SelfDetermination: Moral Foundation for International Law (2004). 
secede in the constitution is not going to make much difference in whether the unit in fact manages to leave the union.

\section{The Virtue of Incompletion}

One serious shortcoming of many constitutions, including those of severely fractured societies, is that those documents attempt to be comprehensive and hence pursue a sense of completion. Completion is a virtue in many areas of life, but not in constitutional design or the structuring of government. Indeed, with respect to constitutional design, especially by severely fractured societies, incompletion is a virtue. ${ }^{54} \mathrm{By}$ incompleteness or incompletion, I mean to suggest that many controversial issues are left for the deliberative process itself. There are a number of reasons why incompletion is a virtue in the designing of constitutional structures and documents. First, many of the most divisive issues, including the very meaning of difference or unity, become terrains of deliberative engagement. Ambiguity on the many divisive issues, at least as an initial matter, is not a bad idea at all. In the course of deliberation, a tradition, though not a text, may develop that may become a focus of consensus. Second, a national constitution that leaves many substantive issues unaddressed is one that leaves space for local organizations and associations, as well as non-governmental actors, to join in the construction of traditions that may best deal with some of the divisive issues. Third, and perhaps most importantly, a national constitution that does not attempt to be comprehensive about finding the solutions to the many thorny substantive issues that plague severely divided societies sends a signal to the various communities that the identity of the state is not defined exclusively by the national government. That signal will reduce the high-stakes competition among the various groups for national power to make the state in their own image. Incompletion will incline groups in severely fractured societies to constitute a more sustainable association by providing an environment in which solutions to thorny identity issues are developed deliberatively and incrementally; ${ }^{55}$ where the deliberative arenas are broadened to include local and non-state actors and fora; and where the intensity of competition among groups to define a unitary, national identity is reduced. John Dryzek is likely correct in his observation that the "very worst repression of

54. Speaking generally abour institutional and conceptual designs, Michael Walzer once observed that "[i]ncompleteness is a virtue ... for it leaves room for local self-determination and cultural diversity." Michael Walzer, Review: The Virtue of Incompletion, 19 THEORY \& SOC'Y 225, 225 (1990).

55. For a discussion of the danger of freezing specific arrangements, see John McGarry \& Brendan O'Leary, Iraq's Constitution of 2005: Liberal Consociation as Political Prescription, 5 INT'L J. CON. L. 670,691 (2007). 
competing identities has often come from actors struggling to secure their hold over a state and the state's hold over a society. ${ }^{156}$

There is another aspect of incompletion worth noting. It is not only in relation to substantive issues that we must refrain from completion but also in terms of language that appears to foreclose the possibility of inclusive alternative patterns for the state by closely associating the dominant group with the state itself. Thus, when the Macedonian constitution makes Macedonia the "national state of the Macedonian people," ${ }^{57}$ thereby linguistically marginalizing the various ethnic minorities within the state, such as the Serbs and Turks, the stage is set for intense conflict over the symbolic capture of the state. This attempt at symbolic completion will distract from the process of constructing national identity through the deliberative process. Declaration of symbolic possession of the state is an impediment rather than a facilitator of deliberation. The same could be said about the declaration of a state to opt for a single official language without a procedure through which the linguistic interests of the various groups have been given equal consideration and respect. ${ }^{58}$

To the extent that a central purpose of deliberation is to shape preferences, beliefs, and identities, and consequently to subject them to reasoned arguments that may result in their transformation, a major goal of a constitutional scheme in severely divided societies must be to protect the deliberative process. This can be done both by leaving major substantive issues to the process and by broadening the participants and fora of deliberation.

\section{The Value of Multiple Spheres of Deliberation}

One aspect of broadening the spheres of deliberation is cultivating deliberative domains in the various constituents' units, where what Cass Sunstein calls "enclave deliberation" 59 could take place. In other words, this is where issues important for the specific ethnic groups are hammered out before they become issues of deliberation on the national level. Such deliberative processes will perform three important functions.

First, to the extent that the particular unit has adopted as its official language a language that is different from the national language, and to the extent that some or

56. DRYZEK, supra note 13 , at 55.

57. Constitution of the Republic of Macedonia pmbl.

58. For a detailed exploration of whether and how commitments to deliberative democracy and to linguistic multiplicity could be reconciled, see generally Adeno Addis, Constitutionalizing Deliberative Democracy in Multilingual Sacieties, 25 BERKELEY J. INT'L L. 117 (2007). See also Addis, supra note 17.

59. SUNSTEIN, supra note 47 , at 15 ("[E]nclave deliberation [is] ... deliberation within small groups of like-minded people."). 
many in that unit speak only the vernacular, local deliberative processes would be more effective in getting the locals engaged in the political life of the unit and the nation. ${ }^{60}$ Second, deliberative processes at the local level will allow ethnic groups to debate and refine issues before those issues are presented as, or become, issues of national concern. Third, as I have already noted, a genuine and autonomous deliberative process at the local level may reduce the intense competition among the various ethnic groups to shape the identity of the nation in their own, often exclusivist, images. The competition for national power in severely divided societies is often a competition for the power to paint an exclusive national identity. It should be noted, however, that experience shows that in some cases, national leaders of multinational states use constituent ethnic units, federal or otherwise, not as entities of local selfdetermination and autonomous deliberation, but rather as tools of decentralized control $^{61}$ used to entrench "the hegemonic state."62 This, of course, is inconsistent with the notion of deliberation that I am advocating.

Another aspect of broadening the deliberative process is including diasporas in the process of constitutional settlement (and hence in the deliberative process). It is abundantly clear that diasporas, especially those from severely divided societics, have played and will continue to play significant roles in the life of their homelands. The diasporas' role in homeland conflicts is well documented. ${ }^{63}$ Diasporas finance

60. See generally Addis, supra note 58 and Addis, supra note 17, for a fuller exploration of this point in relation to deliberation in multilingual societies.

61. Ethiopia is a good example. The current government organized the country into an ethnic federation, with each federal unit supposedly autonomous and with broad power, but as a recent $N e w$ York Times article notes, "Ethiopia is now more or less centrally controlled by members of a small ethnic group." Gettleman, supra note 5; see also Minasse Haile, The New Ethiopian Constitution: Its Impact Upon Unity, Human Rights and Development, 20 Suffolk Transnat'l L. Rev. 1, 44-45, 52 (1996) (discussing the problems of tribalism in Ethiopia). In this respect, Ethiopia is no different from the Soviet Union, which also organized its fifteen constituent republics in ways that corresponded to boundaries and names of dominant ethnic groups so that they could supposedly act autonomously. But the truth was that those republics were controlled from the center and the governments and institutions of those republics were simply local means of central control. The control even had a name, "democratic centralism." Five Constrtutions 29 (S.E. Finer ed., 1979).

62. Ilan Peleg, Democratizing the Hegemonic State 3 (2007) ("I call a state that energetically promotes the interests of a single ethnopolitical group in a multinational setting a hegemonic state.").

63. See SHain, supra note 22, at 101-26. "The diaspora's role in homeland conflict perpetuation and conflict resolution can be so powerful that homeland leaders ignore diaspora preferences at their own peril." Id. at 101 . 
rebellions $^{64}$ and co-ethnics fighting for independence ${ }^{65}$ or fairer terms of cooperation. ${ }^{66}$ At times, they have even organized political parties outside the country or run those which were established within the country from abroad. And yet, despite the widespread recognition of the important role diasporas play in conflict perpetuation as well as conflict resolution in their homelands, there have been no serious attempts intellectually or institutionally to focus on how diasporas could be included in the process of constitutional settlement. It is an essential part of the constitutional settlement of severely fractured societies that there are institutional mechanisms of including diasporas in the process. How they would be represented is a complicated question, but overlooking their significance is not the answer. Diaspora representation in the institutional life of the homeland is not as strange as one may think. It was only a few years ago that Mexico held elections among its expatriates north of the border. The election was to assemble an advisory council of 115 persons within the Institute for Mexicans Abroad that was meant to give advice to the Mexican government on a range of issues. ${ }^{67}$

\section{Electoral Systems and the Deliberative Process}

The nature of the electoral system has a serious impact on the robustness and inclusiveness of the deliberative process, but engineering the appropriate electoral system for a severely divided society is a difficult, even impossible, task. However, the following general outline seems consistent with the notion of deliberative democracy that I have recommended in this article. First, I agree with consociationalists that wide and inclusive representation of all significant groups is important, ${ }^{68}$ for there cannot be full deliberation when some groups are excluded from the delibera-

64. A good example is the Haitian diaspora that financed and organized coups. See generally Michel S. Laguerre, Homeland Political Crisis, the Virtual Diasporic Public Sphere, and Diasporic Politics, 10 J. Latin A.M. ANTHRo. 206 (2005); Walt Bogdanich \& Jenny Nordberg, Mixed U.S. Signals Helped Tilt Haiti Toward Chaos, N.Y. Times, Jan. 29, 2006, at A1.

65. The Tamil diaspora living in Canada and Europe provides substantial resources that sustain the armed struggle for a separate Tamil state in the north and northeastern part of war-torn Sri Lanka. See Daniel Byman et al., Trends in OUtside SupPort for Insurgent Movements 50-53 (2001). For an extensive discussion of the role of diasporas in conflict perpetuation or conflict resolution, see SHAIN, supra note 22, at 101-26.

66. The support of Irish Americans for the Catholics in the Northern Ireland dispute may be viewed in this light.

67. See Oscar Avila, Cicero Lawmaker's Hat in Mexico Race, CHI. Trib., Sept. 22, 2005, at Cl, cited in Anupam Chander, Homeward Bound, 81 N.Y.U. L. Rev. 60, 71 (2006).

68. What constitutes "significance" is a hard question, but it is also clear that one cannot devise a system of proportional representation that includes all ethnic groups regardless of how small the number, for that would make governance rather difficult. But the threshold cannot be too high ei- 
tive process. Indeed, as I argued earlier, it is not only the principle of deliberative equality and hence the principle of political equality that counsels for such inclusion but also the fact that exclusion will reduce the aggregate pool of reason by depriving the deliberative process of the views of certain groups. There cannot be a fair scheme of cooperation when some voices are not heard. This may suggest the adoption of some form of proportional representation for the legislative branch of government. On the other hand, electoral systems, such as those advocated by Horowitz and others who promote incentive-based approaches, are unlikely to be adopted as an initial matter because the potential targets of exclusion and their supporters will not agree to them, or, if they are adopted, will push excluded militants to adopt more radical and perhaps violent ways of undermining the arrangement. That cannot lead to the sort of stability that is the object of such approaches.

Second, although proportional representation might need to be part of the electoral structure, there is no need, on account of either the requirements of the deliberative process or the need for stability, to adopt proportional representation in all spheres of government--legislative, executive, and the bureaucracy-as consociationalists would urge. ${ }^{69}$ There is no virtue in such a uniform approach. Indeed, if deliberation across ethnic groups is to be encouraged, such across-the-board proportional representation may be undesirable. Thus, a severely fractured society that has adopted a parliamentary system and has adopted proportional representation for the legislative branch may, for example, opt to require that members of the government, specifically members of the executive such as cabinet ministers, be chosen under a system that would promote individuals who appeal to members of the other ethnic groups. An example of such a system would be one that requires a cabinet minister to secure weighted-majority support across the whole legislature. ${ }^{70} \mathrm{~A}$ full and unfiltered debate in the legislative body (deliberative equality) may be supplemented and comple-

ther, otherwise the system will exclude all except the large ethnic groups. Alternatively, two or three small ethnic groups may decide to pull together so as to meet the threshold for representation.

69. See AREND LIJPHART, supra note 25, at 125.

70. Ian O'Flynn makes a similar point. One way to achieve a government that will cultivate moderation is "to make government-formation depend on inter-ethnic agreement rather than on automatic appointment, with government ministers having to secure weighted-majority support from across the legislature as a whole (akin to Lebanese Council of Ministers)." Ian O'Flynn, Divided Societies and Deliberative Democracy, 37 BRIT. J. POL. Scr. 731 , 749 (2007). I must note here, however, that the recent open conflict between Hezbollah and the Lebanese government has led to a new pact (brokered by Arab mediators), which by all accounts gives an enhanced role to Hezbollah and its supporters. For details of the agreement, see Robert F. Worth \& Nada Bakri, Lebanon Agreement Shifts Power to Hezbollah, INT'L HERALD .TRIB., May 21, 2008, available at http://www.iht.com/articles/2008/05/21/ africa/22lebanon.php? page $=2$. 
mented with a differently constituted executive branch. The inclusiveness of one branch acts as a complement to the integrative inclination of another branch.

Third, one of the features of consociation is the idea of minority veto. Minority vetoes are assurances that important decisions affecting minorities would not be decided without their consent. From the point of view of deliberative democracy, minority vetoes may perform valuable functions by inclining ethnic groups to develop and offer reasons for their commitments and positions that are acceptable to other ethnic groups and that take their interests and concerns into account. Put simply, minority vetoes may, as paradoxical as it may sound, encourage genuine deliberation. But vetoes have potential drawbacks as well. Not only is there the possibility of paralysis on many issues, but the presence of minority vetoes, just like the constitutionalization of secession, may cause some groups not to take the deliberative process seriously.

To lessen the potential of paralysis and to encourage a genuine deliberative process, institutional protection of minorities may take various forms. For example, the overall requirement of a vote in relation to key decisions such as the budget and the election of speaker of the house may be by supermajority (perhaps 60 percent), with a lower threshold requirement for each ethnic group (perhaps 40 percent of each group must approve). ${ }^{71}$ If a substantial percentage of a minority ethnic group supports a particular decision and that decision garners a supermajority, then it is fair to assume that the reasons offered in support of the decision have been found acceptable, and the decision itself is regarded as a step in the direction of developing fair terms of cooperation. In addition, there could, and perhaps should, be a sunset provision for the minority veto. For example, it could be part of the deal that the issue of minority veto will be revisited in ten years if a simple majority wishes to reconsider the issue. While making it easy to revisit the issue, eliminating the minority veto should, however, still require approval by a significant number of each ethnic group that is part of the coalition or the government. For example, it would not be unreasonable to allow the removal of the minority veto if 60 percent of all members of the legislative body, including at least 40 percent of members of each ethnic group, concur. If such large factions of the various groups agree that the minority veto has outlived its usefulness, then it may be that the deliberative process has in fact made progress in cultivating comfort among the various groups and interethnic solidarity, however thin it may remain.

71. This applies in the Northern Ireland agreement. See PELEG, supra note 62, at 155. 


\section{Conclusion}

Deliberative democracy in plural societies is complex and difficult. It is even more complex and difficult in societies that are severely divided. Critics will certainly argue that deliberative democracy generally, and as I have presented it in this article, is incapable of processing deep difference. However, I have attempted to show that unlike consociational and incentive-based approaches, the deliberative approach simultaneously acknowledges the importance of those differences and the fact that they are constitured partly through narratives and discourses, and consequently could be reconceived or transformed through sustained institutional dialogue among the various groups. In that sense, only deliberative democracy has the capacity to process deep difference. That is so not only because discourse constructs meaning and the relationship among agents, but also because those dialogues and discourse will have been institutionally entrenched, thereby making it possible for the various groups to continue to create and transform their individual and collective identities and interests. Under this account, accommodation may in fact lead to a stronger link among the various contending ethnic groups, one that we may refer to as "pluralistic solidarity."

If one were to label the approach I have presented in this article, it would be "constructivist." It is constructivist to the extent that it views deliberation as a process through which the identities of the participants, not just the policies and institutions of the polity, are constructed and transformed.

In conclusion, I wish to raise an important issue that I hope to explore further in subsequent work. Paying close attention to severely fractured societies and to the establishment of institutions to deal with the problems that such societies face will be valuable for international legal scholars and legal actors. How we resolve the divisions in those societies may give us some clues as to how best we should devise international institutions in a globalized world of divided loyalties and identities. In the same way that groups in severely divided societies are physically close and yet very far apart in terms of allegiances and loyalties, the globalized world has brought countries, systems, and civilizations closer to one another (in trade and communication) without processing the deep differences among them. In the same way that the hegemonic behavior of the multinational or multiethnic state ${ }^{72}$ is a threat to democratic governance and long-term stability of the nation-state, hegemonic behavior on

72. For a description of the hegemonic state, see generally id. at 3. "Hegemonic states, by definition, are committed exclusively to the interests of their dominant ethnic groups." $I d$. at 60 . The hegemony may be majoritarian (the hegemony of the major ethnic group) or minority-based, as with 
the international level is a great threat to international stability. This threat exists because in each case the hegemon seeks to fashion the world around it in its image. Dealing with fracture at the level of the multinational (multiethnic) state may, therefore, give us a sense as to how we might want to deal with fracture at the global or international level. Identity-based fractures will be with us for a long time. In fact, they are likely to intensify as the process of globalization itself intensifies.

white minority rule in South A frica. For a very helpful diagrammatic classification of political systems in severely divided societies, see $i d$. at 79 . 


\section{Indiana University Press/Journals}

\section{International Journal of Feminist Approaches to Bioethics}

... provides a forum within bioethics for feminist thought and debate.

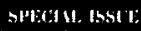

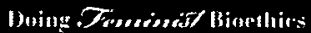

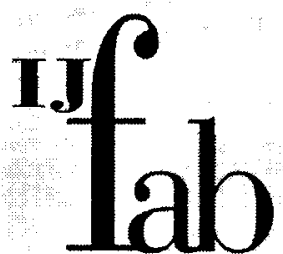

ThandToNal mums or

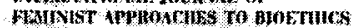
!

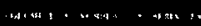

Edited by Mary C. Rawlinson

The International Journal of Feminist Approaches to Bioethics (IJFAB) provides a forum within bioethics for feminist thought and debate. Sponsored by the International Network on Feminist Approaches to Bioethics, IJFAB includes feminist scholarship on ethical issues related to health, health care, and the biomedical sciences. IJFAB aims to demonstrate clearly the necessity and distinctive contributions of feminist scholarship to bioethics. 